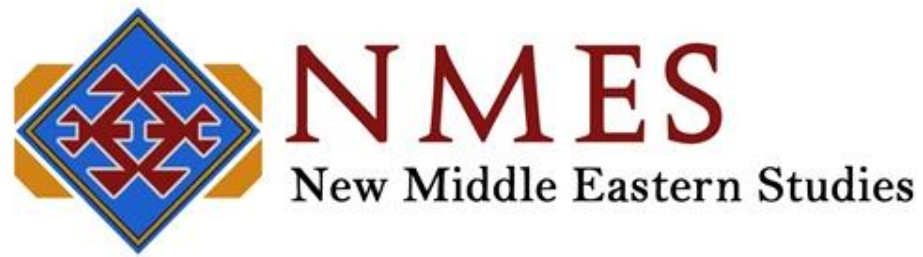

ISSN: 2051-0861

Publication details, including guidelines for submissions:

https://journals.le.ac.uk/ojs1/index.php/nmes

Review of Nergis Canefe, The Syrian Exodus in Context: Crisis, Dispossession and Mobility in the Middle East

Author(s): Maissam Nimer

To cite this article: Nimer, Maissam (2020) "Review of Nergis Canefe, The Syrian Exodus in Context: Crisis, Dispossession and Mobility in the Middle East", New Middle Eastern Studies 10 (1), pp. 120-122.

Online Publication Date: 18 December 2020

\title{
Disclaimer and Copyright
}

The NMES editors make every effort to ensure the accuracy of all the information contained in the journal. However, the Editors and the University of Leicester make no representations or warranties whatsoever as to the accuracy, completeness or suitability for any purpose of the content and disclaim all such representations and warranties whether express or implied to the maximum extent permitted by law. Any views expressed in this publication are the views of the authors and not the views of the Editors or the University of Leicester.

Copyright New Middle Eastern Studies, 2020. All rights reserved. No part of this publication may be reproduced, stored, transmitted or disseminated, in any form, or by any means, without prior written permission from New Middle Eastern Studies, to whom all requests to reproduce copyright material should be directed, in writing.

\section{Terms and Conditions}

This article may be used for research, teaching and private study purposes. Any substantial or systematic reproduction, re-distribution, re-selling, loan or sub-licensing, systematic supply or distribution in any form to anyone is expressly forbidden.

The publisher does not give any warranty express or implied or make any representation that the contents will be complete or accurate or up to date. The accuracy of any instructions, formulae and drug doses should be independently verified with primary sources. The publisher shall not be liable for any loss, actions, claims, proceedings, demand or costs or damages whatsoever or howsoever caused arising directly or indirectly in connection with or arising out of the use of this material. 


\section{NEW MIDDLE EASTERN REVIEWS}

\section{The Syrian Exodus in Context: Crisis, Dispossession and Mobility in the Middle East}

Nergis Canefe

Istanbul Bilgi University Press, 2018, 195 pp., 16 TL (Paperback)

ISBN: 978-605-399-525-8

\section{REVIEWED BY MAISSAM NIMER \\ Postdoctoral Researcher, Istanbul Policy Center at Sabanci University}

Nergis Canefe's The Syrian Exodus in Context: Crisis, Dispossession and Mobility in the Middle East presents itself as focusing on the experiences of dispossession among migrants highlighting their state of precarity reinforced by practices of selective attribution of rights. Structurally, the book consists of an introduction, five essential chapters and a conclusion. The author points at the insufficiency of the literature on forced migration to put the Syrian exodus in context and solicits theories on statehood, labour market restructuring, capital accumulation and critical citizenship. In doing so, her objective is to defend and illustrate that the Syrian crisis is not an anomaly but part of a continuum of forced displacement and takes place in a context of existing global injustices, thus going beyond a state-centric lens. The result is a stimulating argument which examines the current case of displacement in the light of past examples from the author's previous research with displaced communities to further expand on existing frameworks. Its central theme is the exploration of the definition dispossession in forced migration through three lenses: labour studies, citizenship and rights debates.

In the first three chapters, the book sets up the context of refugee reception in the Middle East and North African (MENA) region and at a global level. It first demonstrates that states in the region have used migration as a tool for demographic engineering, by giving examples of displaced communities in Iraq and Turkey and that the Syrian crisis is no exception (Chapter 1). It then shifts the debate to a global level, looking at the European response to refugees and suggests applying ethics of care and collective moral responsibility frameworks to forced migration instead of state-centric liberal ethics through refugee law and selection (Chapter 2). The book further illustrates how host states in the region, namely Iraq, Jordan, Lebanon, and Syria, which have not ratified the 1951 convention on refugee rights and Turkey which maintained the geographical limitation, responded to the refugee influx, by not closing the border but instead adopting ad-hoc policies that aim to incorporate the newly arrived into the labour market to benefit it (Chapter 3). It contributes to the field by pointing at the inadequacy of the traditional human security paradigm to read the reception of regional states and concludes that the Syrian exodus is linked to the need for capital, labour and state legitimacy. In the last two chapters, it introduces the tool of social precarity and analyses how states legalize flexible labour and precarity to serve neoliberal purposes by developing the 
example of Turkey (Chapter 4) and then illustrates the concept through the particular experiences of displaced Syrian women trapped in forced labour and human trafficking (Chapter 5).

In her argument in Chapter 4 ("Managing the Exodus: Syrians in Turkey as Paradigm Shifters"), whereby Turkey takes concrete steps towards the legalization of flexible labour and precarity, Canefe proposes to examine a new framework to understand precarity challenging the division between formal regulated labour and informal unregulated labour. Building on Rygiel's argument that the current understanding of precarity is insufficient to describe the specific challenges of non-citizen and undocumented lives, she focuses (in her article entitled "Invisible Lives: Gender, Dispossession, and Precarity amongst Syrian Refugee Women in the Middle East") on precarity beyond the workplace, concentrating instead on challenges posed by legal status of refugees. In order to do that, she identifies, again, in Chapter 4, several measures taken by the state to highlight that the formalization of precarity in the labour market is state-led. These measures include a decrease in overtime pay or an extension of the time period for flexible working hours. Yet, one fails to see how these measures are applicable to Syrians, the majority of whom are in the informal market. I argue that on the contrary the state did allow Syrians under Temporary Protection to apply for work permits in an apparent effort to regulate and formalize. Yet, by turning a blind eye on the implementation of this regulation, it has contributed to the maintenance and consolidation of flexible labour and precarity. This recent development, which is referred to at the end of the article which came out shortly after, and its impacts could have been further analysed in the book.

Despite the repeated aim of the author of focusing on the experiences of the dispossessed rather than on the perspective of nation-states, the experiences of refugees are not evoked until the fifth chapter. Instead, the author carries out an analysis of states' engagement in the "crisis" which occupies the central part of the book. In Chapter 5 ("Invisible Lives: Gender, Hyper-precarity and Syrian Refugee Women"), the experiences are briefly and vaguely evoked solely based on secondary literature. This unfortunately leads to vast claims and generalizations about "different culture and lifestyle" of "Syrian society" in comparison to the Turkish one, arguing that developing policies for Syrian women assuming they have the same needs as their Turkish counterpart is erroneous. Yet, the portrayal of the Syrian society and its women and "culture" as a homogeneous entity, separate from a Turkish society and its women and "culture", simplifies complex realities. It promotes a binary structure of representation of "us" vs. "them", blurring similarities, differences, transformations and discontinuities which constitute cultures, itself a social construct and reminds of previous practices of othering Kurdish populations.

Further, in that chapter, the author chooses to focus on women only to illustrate the conceptual approach on precarity in the MENA context. The rationale behind this choice is implicit as the author states that she is convinced that Syrian women on the move are singularly disadvantaged, thus linking their experiences to the concept of "hyper-precarity". Yet the demonstration would have benefitted from further references to the gender specific dimension of precarity contrasting the experiences of women (experiences that are not homogenous but vary depending on socio-demographic characteristics among others) with the overall experiences of Syrians. 
While the book sometimes pulls in different directions, the author defends herself from the risk of losing the flow of the argument, in the conclusion, by linking the sections together through the introduction of the concept of statelessness, which she defines and elaborates on. She concludes by re-emphasizing the pre-meditated aspect of the expulsion of dissenters by their country of origin and their absorption to serve political gains and labour market needs, which results in locking "stateless" individuals in "protracted limbo". The conclusion then comes back to the particularities of the MENA region and what they bring to the paradigms which the author had put in question throughout the book, pointing at the importance of looking at transformations in the Global South as a whole, and through an interdisciplinary approach. The book's main strength is that it moves away from studying forced migration as a stand-alone field by integrating debates in other fields. As such, it appeals to academic and non-academic audiences interested in the topics of forced migration as well as labour, law and citizenship, who will find it useful as a tool to understand intersections between these fields. 